\title{
PAJAK ATAS PARKIR BERBAYAR BADAN LAYANAN UMUM
}

\author{
Suparna Wijaya \\ Politeknik Keuangan Negara STAN \\ Zahrona Fatimah \\ Direktorat Jenderal Pajak
}

\begin{abstract}
The public service agency is a central or regional government agency that provides paid services to the community. Usually, public service agencies also provide paid parking, for example, hospitals. In local government parking tax, parking provision carried out by government agencies is excluded from the tax imposition. Meanwhile, the central government in the Value Added Tax (VAT) provisions excludes parking services. So, the purpose of this study is to explain the comparison of the VAT Law and the Local Taxes Law requirement related to parking provision services, describe the relationship between paid parking from the public service agency and the VAT and the Local Taxes Law provision, and explain the ideal taxation of paid parking provision from the public service agency. The research method used is descriptive qualitative. The results clarify that VAT negative list provision in relation to the Local Taxes Law is one way to avoid double taxation on the same object. Paid parking from public service agency is generally one of the exceptions to the imposition of parking taxes according to the Local Taxes Law because it is a parking space administered by the central government and local governments. However, public service agencies may use third-party services to provide paid parking for its parking lot. This paid parking spaces provision service belongs to a public service agency by a third party is a parking tax based on the Local Taxes Law. Meanwhile, the delivery of parking lot management services carried out by third parties is the object of VAT.
\end{abstract}

Keywords: public service agency, local tax, regional distribution, value added tax

\begin{abstract}
ABSTRAK
Badan Layanan Umum (BLU) merupakan instansi pemerintah pusat/daerah yang melayani masyarakat dengan memungut suatu bayaran. Tidak jarang, badan layanan umum juga menyelenggarakan parkir berbayar, contohnya rumah sakit. Pajak parkir yang dikelola pemerintah daerah mengecualikan penyelenggaraan parkir yang dilakukan oleh instansi pemerintah. Sedangkan pemerintah pusat dalam ketentuan Pajak Pertambahan Nilai (PPN) mengecualikan jasa penyelenggaraan parkir. Tujuan penelitian untuk menjelaskan perbandingan UU PPN 1984 dan UU PDRD terkait jasa penyediaan parkir, menjelaskan keterkaitan antara parkir berbayar dari BLU dengan ketentuan PPN dan UU PDRD, dan menjelaskan pemajakan yang ideal atas parkir berbayar dari BLU. Metode penelitian yang digunakan adalah kualitatif deskriptif. Hasil penelitian menjelaskan bahwa adanya negative list PPN dalam hubungannya dengan UU PDRD merupakan salah satu cara untuk menghindari pajak berganda atas suatu objek yang sama. Parkir berbayar dari BLU secara umum merupakan salah satu pengecualian pengenaan pajak parkir menurut UU PDRD karena merupakan penyelenggaraan tempat parkir oleh pemerintah pusat/daerah. Namun, BLU dapat menggunakan jasa pihak ketiga untuk menyelenggarakan parkir berbayar dari tempat parkir miliknya. Atas jasa penyediaan tempat parkir berbayar milik BLU oleh pihak ketiga merupakan ranah pajak parkir berdasarkan UU PDRD. Sementara itu, atas penyerahan jasa pengelolaan tempat parkir yang dilakukan oleh pihak ketiga merupakan objek PPN.
\end{abstract}

Kata Kunci : Badan Layanan Umum, Pajak Daerah, Pajak Pertambahan Nilai, Retribusi Daerah 


\section{PENDAHULUAN}

Tax ratio adalah persentase penerimaan pajak terhadap Produk Domestik Bruto (PDB). Kementerian Keuangan (2019), mengemukakan bahwa kemampuan pemerintah dalam mengumpulkan pajak dari total perekonomian atau dalam arti total PDB dapat diukur menggunakan tax ratio. Besaran tax ratio menunjukkan kemampuan pemerintah dalam mendanai keperluan yang menjadi tanggung jawab negara. Singkatnya, jika tax ratio rendah, secara tidak langsung menunjukkan bahwa pemerintah kurang mampu untuk banyak berbuat melalui Anggaran Pendapatan dan Belanja Negara (APBN). Sebaliknya, jika tax ratio tinggi, dapat diakui bahwa pemerintah lebih banyak menunjukkan kemampuan melalui APBN. Data dari Kementerian Keuangan mengungkapkan bahwa tax ratio Indonesia cenderung rendah jika dibandingkan dengan rata-rata Organization for Economic Cooperation and Development (OECD) yaitu sebesar 34,2\%. Berikut merupakan data tax ratio Indonesia dari tahun 2015 hingga tahun 2019.

Berbicara tentang tax ratio tentunya tidak terlepas dari peran pajak sebagai sumber penerimaan tertinggi bagi negara, termasuk peran berbagai jenis pajak di dalamnya. Jenis pajak yang cenderung mengalami peningkatan adalah Pajak Pertambahan Nilai (PPN). Ketentuan mengenai PPN diatur dalam Undang-Undang (UU) Nomor 8 Tahun 1983 sebagaimana telah beberapa kali diubah terakhir dengan UU Nomor 42 Tahun 2009. McNulty (2000) menyatakan bahwa PPN adalah pajak yang dikenakan atas nilai tambah oleh setiap pengusaha kena pajak. Nataherwin dan Widyasari (2017) menyatakan bahwa PPN memiliki beberapa karakteristik antara lain pajak tidak langsung, pajak objektif, multi-stage tax, dan tidak menimbulkan pajak berganda. Haula et al. (2011) berpendapat bahwa implikasi pengenaan PPN dimulai dengan objeknya seperti keadaan, peristiwa, perbuatan, benda, dan lainnya setelah itu dicari pihak yang bertanggung jawab membayar pajaknya sehingga dimengerti bahwa dasar pengenaan PPN adalah atas ada atau tidaknya objek sebagai titik utamanya. Berbeda dengan pajak lain yang menyebutkan objeknya, UU PPN mengatur tentang barang dan jasa yang tidak dikenakan PPN atau dapat disebut negative list PPN. Le (2003) mengemukakan bahwa pengecualian/negative list ini merupakan suatu hal yang biasa dalam praktik pengenaan PPN. Beberapa negative list tersebut dirasa bergesekan dengan aturan lain yaitu UU Nomor 28 Tahun 2009 tentang Pajak Daerah dan Retribusi Daerah (PDRD) yang selanjutnya disebut UU PDRD. Peraturan pelaksanaan mengenai pajak daerah diatur oleh pemerintah daerah baik pemerintah kota maupun pemerintah kabupaten.

Tidak hanya itu, kegiatan bisnis yang semakin berkembang juga dapat menyebabkan timbulnya permasalahan lain ketika tidak hanya ada penyerahan Barang Kena Pajak (BKP), tetapi juga penyerahan non BKP atau dapat disebut Jasa Kena Pajak (JKP). Beberapa jenis jasa yang termasuk dalam negative list PPN menjadi pengecualian dalam pengenaan PPN karena telah dikenakan pajak daerah berdasarkan UU PDRD. Jasa tersebut di antaranya adalah jasa perhotelan, jasa boga, jasa hiburan, dan jasa penyediaan parkir. Salah satu hal yang cukup menarik adalah terkait jasa penyediaan parkir. Menurut Abubakar et al. (1998), parkir adalah keadaan suatu kendaraan yang tidak bergerak yang bersifat sementara.

Menurut Mardiasmo (2016), pengelompokan atau klasifikasi pajak menurut lembaga pemungutnya ada dua yaitu pajak pusat dan pajak daerah. Bird dan Wilkie (2012, dikutip dalam Satifah, 2020), pemerintah sering menggunakan sistem pajak sebagai alat untuk mendorong atau mengubah keadaaan ekonomi tertentu. Selain itu, Smith (2007, dikutip dalam Wong, 2015) menyatakan bahwa pajak bertujuan untuk mempengaruhi pilihan wajib pajak. Menurut World Bank (1999, dikutip dalam Noor, 2012), diperlukan kekuasaan baik politik, fiskal, maupun pemerintahan kepada pemerintah daerah dalam desentralisasi, termasuk adanya pajak daerah. Pajak atas 
penyediaan parkir merupakan objek pajak daerah berdasarkan UU PDRD dan merupakan negative list PPN. Namun, yang menjadi salah satu permasalahan adalah ketika parkir tersebut diselenggarakan oleh pemerintah. UU PPN mengecualikan objek tersebut karena telah diatur oleh UU PDRD yang kemudian dipungut oleh daerah. Ternyata, dalam UU PDRD juga mengecualikan pengenaan pajak parkir apabila diselenggarakan oleh pemerintah.

Contoh nyata dari pemerintah yang menyelenggarakan parkir berbayar adalah Badan Layanan Umum (BLU), baik pusat maupun daerah. Badan Layanan Umum (BLU) berdasarkan Undang-Undang Nomor 1 Tahun 2004 tentang Perbendaharaan Negara, merupakan suatu instansi pemerintah untuk melayani masyarakat tanpa mengutamakan mencari keuntungan dan dalam melakukan kegiatannya didasarkan pada prinsip efisiensi dan produktivitas. Salah satu contoh BLU adalah rumah sakit pemerintah. Pihak rumah sakit menyediakan tempat parkir dan atas parkir tersebut dikenakan tarif yang akan dibayar oleh penerima jasa. Singkatnya, atas parkir yang dipungut bayaran tersebut jika dilihat dari pihak yang menyelenggarakan, jasa tersebut tidak dikenakan pajak baik PPN karena merupakan negative list PPN maupun pajak parkir yang dikecualikan dalam UU PDRD. Padahal pajak parkir sendiri diperlukan sebagai salah satu penopang sumber keuangan daerah. Hutagalung (2016) menyatakan bahwa keuangan daerah merupakan setiap hak dan kewajiban daerah yang dapat dinilai dengan uang termasuk segala bentuk kekayaan daerah yang digunakan untuk menyelenggarakan pemerintahan daerah.

Penelitian tentang pajak parkir pada umumnya membahas efektivitas penerimaan pajak parkir terhadap pendapatan asli daerah (Amanto \& Andri, 2014; Aprillitawati, 2013; Arditia, 2013; Butarbutar, 2015; Erawati \& Rahmawati, 2016; Estiningsih \& Nurranto, 2020; Gandasari et al., 2020; Gintoe, S., Elim \& Mawikere, 2018; Gusful, 2015; Kesek, 2013; Landeng et al., 2021; Lubis \& Yando, 2019; Maharani \& Rosyid, 2014; Makausi et al., 2019; Malombeke, 2016; Manopo et al., 2020; Mosal, 2013; Mufidah \& Susyanti, 2017; Mustoffa, 2018; Mutiarahajarani et al., 2018; Pangau et al., 2019; Pangerapan \& Wokas, 2016; Pashaputra et al., 2017; Payu, 2014; Prananda et al., 2020; Rahmadhini, 2015; Religia \& Pratomo, 2014; Rosyid et al., 2015; Subagiyo, 2018; Tulandi et al., 2020; Tumanduk et al., 2021; Vamiagustin, 2014; Wicaksono \& Puspita, 2020; Widjaya et al., 2018; Widuri et al., 2020), strategi peningkatan pajak parkir (Fajriana, 2017; Kadaryanto \& Utama, 2020; Pamasi et al., 2018), sistem informasi parkir (Hutagalung, 2017), pengembangan wilayah parkir (Haikal, 2018), analisis keuangan tempat parkir (Chandra et al., 2021; Kasuma, 2011; Kormomolin et al., 10M; Mujib, 2020), dan pajak penghasilan atas parkir (Kumaratih et al., 2018).

Hani \& Djasuli (2015) meneliti Fenomena Lorong-Lorong Gelap Kebocoran Pajak dan Retribusi Parkir di Surabaya. Hasil penelitian menunjukkan bahwa terjadinya kebocoran pajak dan retribusi parkir disebabkan salah satunya karena kebijakan perpajakan yang masih belum jelas. Penelitian yang dilakukan sebagai upaya untuk menindaklanjuti Hani \& Djasuli (2015) terhadap kebijakan parkir antara PPN dan pajak parkir.

Nugroho (2006) berdasarkan hasil penelitiannya menemukan bahwa terdapat pajak berganda di bidang perparkiran, hal ini dikarenakan adanya pajak pertambahan nilai atas jasa pengelolaan parkir. Namun hasil penelitian ini berbeda dengan Sa'adah (2018) menunjukkan bahwa pajak parkir disandingkan dengan pemungutan Pajak Penghasilan (PPh) dan Pajak Pertambahan Nilai (PPN) baik dilihat dari objek dan wajib pajaknya tidak terdapat kegandaan. Namun demikian, baik penelitian Nugroho (2006) dan Sa'adah (2018) hanya membandingkan secara umum saja terhadap pajak parkir yang dipungut oleh suatu perusahaan. Adapun perbedaan dengan penelitian yang dilakukan adalah melihat parkir yang diselenggarakan oleh Badan Layanan Umum (BLU). 
Berbeda dengan Puspitasari (2015) yang dalam penelitiannya hanya mengulas pengenaan pajak pertambahan nilai atas jasa sewa lahan di salah satu pasar di Surabaya. Hal ini berbeda dengan yang dilakukan dalam penelitian ini yang memfokuskan kepada penyelenggaraan parkir, bukan jasa sewa lahan untuk parkir.

Adapun Susanto (2016) hanya menjelaskan perbedaan pajak parkir dan PPN yang dikenakan sehubungan dengan usaha parkir secara umum. Sangat jauh berbeda dengan penelitian ini yang membahas jasa penyelenggaraan parkir yang dilakukan oleh Badan Layanan Umum (BLU) dari sisi pajak parkir dan pajak pertambahan nilai. Hal ini penting dilakukan karena penyelenggaraan parkir terdapat dalam negative list PPN sehingga tidak akan dikenakan PPN. Berkaitan dengan hal tersebut, dalam pajak parkir sendiri, penyelenggaraan parkir yang dilakukan oleh pemerintah juga dikecualikan dari pengenaan pajak parkir. Padahal Badan Layanan Umum (BLU) sebagai instansi pemerintah menyelenggarakan parkir berbayar.

Melihat masih terbatasnya penelitian terkait jasa penyelenggaraan parkir berbayar yang dilakukan oleh BLU dari sisi pajak parkir dan PPN, penelitian diarahkan untuk melakukan dengan tujuan untuk menjelaskan persandingan ketentuan dalam negative list PPN dengan UU PDRD terkait jasa penyediaan parkir, menjelaskan keterkaitan antara parkir berbayar dari BLU dengan ketentuan negative list PPN dan UU PDRD, dan menjelaskan pengenaan pajak atas parkir berbayar dari BLU.

\section{METODE DAN DATA}

Metode penelitian yang digunakan adalah kualitatif deskriptif. Penelitian menggunakan dua data yaitu sekunder dan primer. Data sekunder diperoleh dari studi pustaka. Nazir (2013) menyatakan bahwa studi pustaka merupakan teknik pengumpulan data dengan melakukan pengkajian terhadap buku-buku, literatur-literatur, catatan-catatan, dan laporan yang berhubungan dengan masalah yang akan dibahas. Dengan cara ini, penelitian berupaya mengumpulkan, membaca, dan mempelajari berbagai literatur yang bersumber dari buku, peraturan perundang-undangan, artikel dan jurnal ilmiah terkait dengan pengenaan pajak atas parkir berbayar dari BLU.

Sedangkan data primer diperoleh dengan menggunakan wawancara. Wawancara dilakukan dengan tiga orang narasumber yang dinilai dapat berpengaruh terhadap hasil penelitian. Jenis yang dipilih adalah wawancara mendalam atau indepth interview. Moleong (2005) menyatakan bahwa wawancara mendalam adalah suatu proses menggali informasi dengan tetap terarah pada pusat penelitian tetapi dilakukan secara mendalam, terbuka, dan bebas dengan masalah dan fokus penelitian. Melalui metode tersebut, wawancara yang terlaksana lebih dapat bersifat eksploratif tetapi masih dalam area penelitian. Narasumber penelitian yang telah diwawancarai adalah pihak yang memiliki pengetahuan yang luas mengenai aturan dan ketentuan terkait topik penelitian, yaitu dari Direktorat Jenderal Perimbangan Keuangan (DJPK), dosen Politeknik Keuangan Negara (PKN) STAN, dan Direktorat Jenderal Pajak. Triangulasi digunakan untuk membandingkan hasil wawancara dari beberapa narasumber dengan ketentuan peraturan perpajakan yang ada dalam rangka membuktikan kebenaran dari informasi yang telah disampaikan.

\section{PEMBAHASAN}

\subsection{Jasa Penyediaan Parkir dalam Negative List PPN dan UU PDRD}


Pengenaan PPN berbeda dengan pengenaan pajak lain yang bersifat subjektif. PPN menekankan pada ada atau tidaknya suatu barang dan jasa yang termasuk dalam objek PPN. Hal ini sejalan dengan pendapat Haula et al. (2011) yang menyatakan bahwa implikasi pengenaan PPN dimulai dengan objeknya seperti keadaan, peristiwa, perbuatan, benda, dan lainnya setelah itu dicari pihak yang bertanggung jawab membayar pajaknya sehingga dimengerti bahwa dasar pengenaan PPN adalah atas ada atau tidaknya objek sebagai titik utamanya.

Lebih lanjut, jika dilihat dalam aturannya yaitu UU PPN, PPN dikenakan hampir setiap lini kegiatan usaha dan tidak mengidentifikasi secara khusus untuk setiap objek pajaknya. Terkait dengan hal tersebut, UU PPN justru mengatur beberapa jenis barang dan jasa yang tidak dikenakan PPN atau dapat disebut negative list PPN. Kelompok barang dan jasa yang tidak dikenakan PPN tertera dalam Pasal 4A ayat (2) dan (3) UU PPN.

Menurut NS1 (2021), adanya negative list PPN tersebut merupakan suatu kebijakan yang telah diperhitungkan oleh pemerintah. Pendapat ini sejalan dengan penelitian Le (2003) yang menyatakan perlunya exemption dalam pengenaan PPN. Kebijakan terkait pengecualian pengenaan PPN atas suatu barang dan jasa tentunya memiliki tujuan yang akan dicapai. Salah satu tujuan yang paling dekat bagi setiap orang adalah agar dapat membantu masyarakat dalam memenuhi kebutuhan pokoknya dan tidak merasa terganggu akan adanya pemungutan PPN atas barang/jasa yang bersifat primer sehingga dapat terwujud kemaslahatan umat.

Adanya ketentuan negative list ini merupakan upaya pemerintah untuk menghindari adanya pajak berganda yaitu adanya dua pokok pajak atas suatu objek tertentu. Jika melihat klasifikasi pajak berdasarkan lembaga pemungutnya, terdapat dua jenis pajak yaitu pajak pusat dan pajak daerah. Kedua jenis pajak tersebut memiliki dasar hukum yang berbeda di mana pajak daerah merupakan kewenangan daerah. Ketentuan pemajakan pusat dan daerah ini perlu diselaraskan agar tidak menimbulkan pajak berganda. Pertimbangan ini didukung oleh pendapat NS2 (2021) terkait adanya ketentuan negative list PPN yang bersinggungan dengan UU PDRD yang menjelaskan bahwa secara teknis pengawasannya lebih sesuai jika diawasi oleh pemerintah daerah. Pengaturan negative list PPN yang mengacu pada UU PPN sebagai pajak pusat, dalam implementasinya perlu diselaraskan dengan objek pajak dalam UU PDRD agar tidak menimbulkan pajak berganda.

Pemerintah pusat telah memberikan kewenangan kepada pemerintah daerah untuk melaksanakan desentralisasi. Perwujudan dari desentralisasi adalah otonomi daerah di mana pemerintah daerah memiliki hak, wewenang, dan kewajiban untuk mengatur dan mengurus rumah tangganya sendiri sesuai dengan peraturan perundang-undangan yang berlaku, termasuk dalam pemungutan pajaknya. Hal ini sejalan dengan pendapat Cohen dan Peterson (1999, dikutip dalam Noor, 2012) yang mengemukakan bahwa desentralisasi dapat disebut telah berjalan jika pemerintah daerah secara resmi dan legal mengumpulkan pajak daerah dan pendapatan lain.

Dalam kaitannya dengan UU PDRD, beberapa jenis barang atau jasa yang tidak dikenakan PPN sejalan dengan pengenaan pajak daerah atas objek tersebut. Setidaknya terdapat satu jenis kelompok barang dan lima jenis jasa yang merupakan negative list PPN yang berkaitan dengan ketentuan dalam UU PDRD. Negative list PPN tersebut berhubungan dengan pengenaan pajak daerah berupa pajak hotel, pajak restoran, pajak hiburan, dan pajak parkir.

Pemungutan pajak hotel oleh pemerintah daerah berkaitan dengan jasa perhotelan yang termasuk dalam negative list PPN. Penjelasan Pasal 4A ayat (3) huruf I UU PPN menyebutkan bahwa jasa perhotelan meliputi jasa penyewaan kamar termasuk tambahan atau fasilitas terkait dan jasa penyewaan ruangan untuk kegiatan acara di hotel. Ketentuan negative list ini sejalan dengan objek pajak hotel yaitu atas pelayanan yang disediakan oleh hotel. 
Pajak restoran merupakan pajak yang dikenakan atas pelayanan yang disediakan oleh restoran. Jenis pajak ini berkaitan dengan negative list PPN berupa makanan dan minuman yang disajikan di hotel, restoran, rumah makan, warung, dan sejenisnya baik yang dikonsumsi di tempat maupun tidak. Termasuk di dalamnya yaitu makanan dan minuman yang diserahkan oleh usaha jasa boga atau katering. Peraturan Menteri Keuangan Nomor 18/PMK.010/2015 tentang Kriteria Jasa Boga atau Katering yang Termasuk dalam Jenis Jasa yang Tidak Dikenai PPN menyebutkan bahwa atas jasa boga dan katering tidak dikenai PPN, termasuk makanan atau minuman yang menjadi bagian tidak terpisahkan dari penyerahan jasa tersebut. Namun, untuk penjualan makanan atau minuman yang dilakukan melalui tempat penjualan berupa toko, kios, dan sejenisnya baik langsung maupun melalui pesanan tetap merupakan objek PPN.

Pajak hiburan berkaitan dengan negative list PPN berupa jasa pelayanan sosial serta jasa kesenian dan hiburan. Peraturan Menteri Keuangan Nomor 158/PMK.010/2015 tentang Kriteria Jasa Kesenian dan Hiburan yang Tidak Dikenai PPN menyebutkan bahwa jasa kesenian dan hiburan yang tidak dikenai PPN meliputi semua jenis jasa yang dilakukan oleh pekerja seni dan hiburan. Jenis jasa tersebut dijabarkan lebih lanjut yang kemudian diketahui merupakan objek pajak daerah berupa pajak hiburan yang dikenakan atas penyelenggaraan hiburan.

Menurut NS1 (2021), penetapan beberapa objek pajak daerah yang terkait dengan negative list PPN dilakukan dengan berbagai pertimbangan, termasuk melihat kedekatan dari objek pajaknya. Dengan adanya objek-objek pajak yang dipungut oleh daerah, diharapkan mampu meningkatkan penerimaan atau Pendapatan Asli Daerah (PAD). Selain itu, perlakuan tersebut ditetapkan dengan harapan agar daerah dapat lebih mandiri dan optimal dalam mengelola keuangan daerahnya.

Parkir merupakan suatu kondisi tidak bergerak dari kendaraan yang sifatnya sementara ketika kendaraan membutuhkan tempat pemberhentian.setelah berjalan menuju suatu tempat tujuan. Tempat pemberhentian tersebut dapat berupa fasilitas parkir untuk umum yang disediakan untuk memenuhi kebutuhan fasilitas parkir pada kawasan tertentu. Fasilitas parkir ini dapat diusahakan sebagai suatu kegiatan usaha yang berdiri sendiri dengan memungut bayaran bagi pengguna jasanya maupun tidak memungut bayaran.

Menurut NS2 (2021), saat ini bisnis parkir semakin bertumbuh mengingat pemakaian kendaraan bermotor yang semakin meningkat. Dengan adanya fenomena tersebut, pihak pengusaha melihat adanya peluang untuk menyediakan fasilitas parkir. Selain itu, dengan disediakannya tempat atau fasilitas parkir dapat mengoptimalkan penggunaan aset yang dimiliki oleh pihak pengusaha tersebut. Adanya konsumsi masyarakat atas penggunaan fasilitas dan peningkatan pendapatan pengusaha secara tidak langsung dapat meningkatkan penerimaan negara.

Pendapat tersebut sejalan dengan Abubakar et al. (1998) yang menyampaikan bahwa usaha penyediaan fasilitas parkir untuk umum meliputi kawasan-kawasan tertentu yang dianggap dapat membangkitkan pergerakan lalu lintas, seperti di pusat perbelanjaan, pusat bisnis, dan area perkantoran. Kawasan tersebut sudah tidak asing lagi di kota-kota besar. Pusat perbelanjaan dan gedung perkantoran dapat menyediakan fasilitas parkir baik berupa taman parkir maupun gedung parkir yang memungut bayaran.

Salah satu jenis jasa yang tidak dikenai PPN adalah jasa penyediaan tempat parkir sebagaimana disebutkan dalam Pasal 4A ayat (3) huruf n UU PPN. Dalam penjelasannya, disebutkan bahwa jasa penyediaan tempat parkir adalah jasa penyediaan tempat parkir yang dilakukan oleh pemilik tempat parkir atau pengusaha kepada pengguna tempat parkir dengan dipungut bayaran. Bersinggungan dengan negative list tersebut, UU PDRD menyebutkan salah satu jenis pajak kabupaten atau kota yaitu pajak parkir. Objek pajak parkir adalah penyelenggaraan tempat parkir di 
luar badan jalan, baik yang disediakan berkaitan dengan pokok usaha maupun yang disediakan sebagai suatu usaha. Termasuk di dalamnya adalah penyediaan tempat penitipan kendaraan bermotor.

Aturan lain yang terkait yaitu Peraturan Menteri Keuangan Nomor 122/PMK.03/2012 tentang Kriteria Jasa Penyediaan Tempat Parkir yang Termasuk dalam Jenis Jasa yang Tidak Dikenai Pajak Pertambahan Nilai. Dalam PMK ini, disampaikan bahwa PPN hanya dikenakan atas penyerahan jasa pengelolaan tempat parkir, bukan atas penyerahan jasa penyediaan tempat parkir. Jasa pengelolaan tempat parkir adalah jasa yang dilakukan untuk mengelola tempat parkir yang dimiliki atau disediakan oleh pemilik tempat parkir. Dalam kegiatannya, pengusaha pengelola tempat parkir menerima imbalan dari pemilik tempat parkir, termasuk imbalan dalam bentuk bagi hasil.

PMK ini mendefinisikan pengusaha pengelola tempat parkir sebagai orang atau badan yang mengelola tempat parkir yang telah disediakan oleh pihak yang memiliki tempat parkir, termasuk pengelola valet parking. Jika dilihat dari definisi tersebut, berarti tidak menutup kemungkinan bahwa pihak pengelola tempat parkir berbeda dengan pihak pemilik tempat parkir. Dengan kata lain, pemilik tempat parkir dapat menggunakan jasa pihak ketiga yang merupakan pengusaha pengelola tempat parkir untuk mengelola tempat parkirnya.

Berbeda dengan jasa pengelola tempat parkir, atas penyerahan jasa penyediaan tempat parkir tidak dikenai PPN. Dalam PMK ini, jasa penyediaan tempat parkir adalah jasa penyediaan atau penyelenggaraan tempat parkir yang dilakukan oleh pemilik tempat parkir ataupun pengusaha pengelola tempat parkir dengan memungut bayaran kepada pengguna jasanya. Pengertian tersebut berarti bahwa yang termasuk dalam penyedia tempat parkir adalah pihak yang merupakan pemilik tempat parkir ataupun pihak yang mengelola tempat parkir.

Atas jasa atau fasilitas parkir yang disediakan oleh pengusaha, terdapat beberapa jenis pungutan daerah yaitu pajak parkir, retribusi jasa umum, dan retribusi jasa usaha. Ketiganya tentu memiliki perbedaan meskipun sama-sama ranah pemungutan yang dilakukan oleh pemerintah daerah. NS2 (2021) berpendapat secara konsep pajak diartikan iuran yang tidak mendapatkan imbalan langsung. Karenanya kurang tepat jika pajak atas penyediaan parkir dijadikan landasan pengenaan pajak karena ada manfaat yang didapatkan langsung. Jika demikian halnya, maka lebih tepat jasa penyediaan parkir masuk dalam kategori retribusi yang dikelola oleh pemerintah daerah.

Berarti, menurut NS2 (2021) terdapat perbedaan pajak dan retribusi dari sisi kontraprestasi dapat menjadi salah satu pemilah ranah pemungutan antara pusat dan daerah. Perbedaan dari sisi kontraprestasi merupakan hal yang mencolok mengingat salah satu poin dalam definisi pajak adalah tidak adanya timbal balik yang dapat langsung dirasakan oleh wajib pajak.

Pajak akan masuk menjadi komponen penerimaan negara dan disalurkan kembali untuk masyarakat dalam bentuk pengeluaran dan belanja negara sehingga wajib pajak tidak dapat merasakan imbalannya secara langsung. Lain halnya dengan retribusi di mana ketika seseorang telah membayar retribusi, orang tersebut dapat merasakan imbalannya secara langsung. Misalkan ketika Tuan A melakukan parkir di bahu jalan lalu membayar retribusi parkir, Tuan A dapat merasakan kontraprestasinya secara langsung dengan mendapat layanan dan keamanan atas kendaraannya.

Retribusi atas parkir sendiri dibedakan menjadi dua yaitu retribusi jasa umum berupa pelayanan parkir di tepi jalan umum dan retribusi jasa usaha berupa tempat khusus parkir. Dalam UU PDRD, objek pelayanan parkir di tepi jalan umum adalah penyediaan pelayanan parkir di tepi jalan umum yang telah ditentukan berdasarkan peraturan daerah. Lain halnya dengan objek retribusi tempat khusus parkir yaitu atas pelayanan tempat khusus parkir baik yang disediakan, dimiliki, maupun dikelola oleh pemerintah daerah. Selain kedua retribusi tersebut, pemerintah daerah juga 


\section{1 | Bina Ekonomi}

berwenang untuk memungut pajak parkir atas penyelenggaraan tempat parkir di luar badan jalan termasuk penyediaan tempat penitipan kendaraan bermotor.

NS1 juga membedakan ketiga jenis pungutan daerah tersebut. Pajak parkir dikenakan atas disediakannya tempat parkir karena adanya usaha seperti di mal atau gedung parkir. Sementara itu, retribusi pelayanan parkir yang termasuk retribusi umum biasa dipungut oleh daerah pada bahubahu jalan umum yang ada di daerah misalnya mobil-mobil yang terparkir di bahu jalan daerah Pasar Baru. Berbeda lagi dengan retribusi tempat khusus parkir yang disediakan khusus oleh daerah. Tempat parkir ini bukan di lokasi komersial ataupun bahu jalan tetapi di suatu tempat yang membutuhkan lahan yang besar seperti di tempat khusus parkir yang disediakan di tempat wisata dan lahan parkir bandara yang disediakan oleh pemerintah daerah.

\subsection{Parkir Berbayar dari BLU dan Kaitannya dengan Aturan}

UU PDRD menetapkan tiga macam penyelenggaraan tempat parkir yang tidak termasuk objek pajak parkir. NS1 (2021) menjelaskan bahwa pengecualian pajak parkir ini tentu sudah disesuaikan kebutuhan atau kebutuhan daerah. Jadi kalau seandainya beberapa pengecualian pajak parkir ini itu di antaranya adalah penyelenggaraan tempat parkir oleh pemerintah pusat dan pemerintah daerah. Yang kedua penyelenggaraan tempat parkir oleh kantor yang hanya digunakan untuk karyawan sendiri dan penyelenggaraan tempat parkir oleh kedutaan konsulat dan perwakilan negara asing dengan asas timbal balik dan penyelenggaraan tempat parkir lainnya.

Pendapat ini sejalan dengan ketentuan yang ada dalam UU PDRD, salah satunya yaitu bahwa pajak parkir tidak dikenakan atas tempat parkir yang diselenggarakan oleh pemerintah pusat dan daerah. Pihak pemerintah pusat dan daerah yang dimaksud adalah segenap jajaran yang menjalankan tata administrasi pemerintahan termasuk badan layanan umum. BLU merupakan bagian dari instansi pemerintah yang memberikan layanan berupa penyediaan barang atau jasa kepada masyarakat, termasuk BLUD yang menjadi bagian dari pemerintah daerah.

Pajak parkir juga tidak dikenakan atas tempat parkir yang diselenggarakan oleh perkantoran dan hanya digunakan untuk karyawannya sendiri atau pihak internal. Ketentuan ini sejalan dengan pengertian pengecualian yaitu jika atas objek tersebut dikenakan pajak parkir justru tidak mencerminkan keadilan. Perlakuan ini dapat berbeda apabila area perkantoran tersebut juga digunakan oleh pihak lain. Pemerintah daerah dapat mengatur lebih lanjut melalui peraturan daerah masing-masing terkait hal tersebut.

Atas penyelenggaraan tempat parkir oleh kedutaan, konsulat, dan perwakilan negara asing tidak dikenakan pajak parkir sepanjang adanya asas timbal balik. Asas timbal balik berarti bahwa terdapat perlakuan perpajakan yang sama antara suatu negara dengan perwakilan negara Indonesia berdasarkan suatu persetujuan. Terkait dengan pengecualian ini, NS1 (2021) berpendapat untuk tempat parkir apabila di satu tempat ada kedutaan, konsulat dan perwakilan negara asing itu juga bisa dikecualikan tidak dipungut parkir. Jadi ini pun berdasarkan asas timbal balik. Asas timbal balik itu maksudnya apabila warga negara tersebut juga memberikan fasilitas yang sama kepada warga Indonesia di negara tersebut.

Ketiga pengecualian yang ada berlaku apabila dalam penyediaannya, tempat parkir langsung diselenggarakan oleh pihak-pihak terkait sebagaimana telah disebutkan sebelumnya. Ketentuan ini berbeda jika penyelenggaraannya diserahkan kepada pihak lain atau pihak ketiga, seperti suatu gedung yang disewakan untuk bersama baik untuk pihak perkantoran pemerintah maupun untuk pihak swasta. 
Sementara itu, UU PDRD juga menetapkan bahwa pemerintah daerah berwenang untuk menambah pengecualian atas objek pengenaan pajak parkir yang selanjutnya diatur dalam peraturan daerah masing-masing dan secara jelas ditetapkan. Penetapan ini dapat disesuaikan dengan kondisi dan potensi yang ada pada masing-masing daerah. Sebagai contoh, di Banjarmasin dan Batu, pemerintah daerahnya menetapkan bahwa atas tempat parkir yang diselenggarakan oleh institusi pendidikan dan pengelola tempat ibadah tidak dikenai pajak parkir. Pemerintah DKI Jakarta justru mengecualikan pengenaan pajak parkir atas penyelenggaraan penitipan kendaraan bermotor dengan kapasitas sampai dengan sepuluh kendaraan roda empat atau lebih dan kapasitas sampai dengan dua puluh kendaraan roda dua serta dan penyelenggaraan tempat parkir yang semata-mata digunakan untuk usaha memperdagangkan kendaraan bermotor dalam peraturan daerahnya.

Pengecualian pengenaan pajak parkir dapat disesuaikan dengan kebutuhan masing-masing daerah. NS1 (2021) berpendapat semua pengecualiannya tentu ada sebab dan alasan. Penetapan pengecualian sudah merupakan pemikiran matang dari pemerintah daerah. Apabila tempat parkir itu digunakan untuk karyawan sendiri itu bisa jadi pengecualian. Ketentuan pengecualian ini diterbitkan oleh pemerintah daerah.

Berarti, penetapan tersebut merupakan hasil pemikiran matang yang dilakukan oleh pemerintah daerah. Setiap daerah dapat menetapkan perlakuan yang berbeda atas pengecualian pengenaan pajak parkir termasuk menetapkan instansi ataupun BLU yang tidak dikenai pajak parkir. Adanya statement dan ketentuan yang jelas dalam peraturan daerah merupakan sesuatu yang paling utama dari adanya pengecualian ini. Aturan yang mendasari pengenaan pajak tersebut juga merupakan perwujudan dari asas certainty yang mewajibkan pemerintah untuk memberikan suatu kepastian hukum bagi wajib pajak dalam memenuhi hak dan kewajiban perpajakannya.

Dalam penyediaan parkir berbayar, tidak sedikit instansi pemerintah termasuk BLU yang menyerahkannya untuk dikelola oleh pihak ketiga. Jika diserahkan kepada pihak ketiga, pihak ketiga akan bersikap profesional dan tidak mengenal adanya pengecualian atas karyawan maupun pihak internal lainnya. Pihak ketiga akan tetap memungut bayaran atas parkir kepada semua pihak secara normal sebagaimana berlaku secara umum. Pernyataan ini didukung dengan pendapat NS1 (2021), terkait dengan BLU memang untuk perparkiran ini bisa diserahkan kepada pihak ketiga atau di outsourcing-kan. Banyak parkir itu yang dikelola oleh pihak ketiga. Misalnya di Jakarta ada secureparking dan banyak lagi yang dikelola oleh pihak ketiga. Nah kalau dikelola pihak ketiga ini itu profesional gitu. Siapapun itu akan dikenakan beban parkir.

Namun, terdapat fasilitas khusus yang dimiliki oleh pegawai terkait parkir berbayar yang ada yang merupakan kebijakan dari instansi atau perusahaan. Fasilitas tersebut dapat berupa voucher atau penggantian. Menurut NS1 (2021), sejalan dengan adanya pengecualian pengenaan pajak parkir dalam UU PDRD, pihak penyedia tempat parkir dapat memberikan keringanan terlebih untuk orangorang yang terkait langsung. Pihak yang terkait langsung ini meliputi pihak internal atau karyawan.

Merujuk pada ketentuan yang tertera dalam UU PDRD terkait pengecualian pajak parkir yang diselenggarakan oleh pemerintah dan pemerintah daerah, pajak parkir tidak dikenakan hanya jika tempat parkir langsung diselenggarakan oleh pemerintah dan pemerintah daerah termasuk BLU. Berarti, pengecualian ini hanya berlaku apabila BLU merupakan pihak yang menyediakan tempat sekaligus menyelenggarakan parkir berbayar. BLU menyediakan tempat khusus parkir yang kemudian atas penyediaan tempat tersebut, pengunjung dipungut bayaran oleh BLU.

Sebagai contoh, suatu BLU berupa rumah sakit memiliki suatu lahan yang digunakan untuk parkir. Rumah sakit tersebut kemudian secara mandiri menyediakan tempat parkir berbayar dan tidak menggunakan jasa pihak ketiga untuk penyelenggaraannya. Maka, penyediaan tempat parkir 


\section{3 | Bina Ekonomi}

berbayar oleh pihak rumah sakit dapat tergolong dalam pengecualian pengenaan pajak parkir berdasarkan UU PDRD yaitu atas penyelenggaraan tempat parkir oleh pemerintah.

Bersinggungan dengan hal tersebut, jika melihat ketentuan terkait retribusi jasa usaha dalam UU PDRD, objek retribusi jasa usaha adalah pelayanan yang disediakan oleh pemerintah daerah dengan menganut prinsip komersial. Berarti, contoh rumah sakit yang menyediakan tempat parkir berbayar tersebut dapat menjadi objek retribusi ini. Atas bayaran yang dipungut oleh pihak rumah sakit dapat diklasifikasikan sebagai pungutan retribusi jasa usaha berupa tempat khusus parkir yang disediakan oleh BLU.

Perlakuan berbeda tentu diterapkan apabila penyelenggaraan tempat parkir milik BLU tersebut diserahkan kepada pihak ketiga. Penjelasan ini didukung dengan pendapat NS3 (2021) bahwa masih bisa dilihat lagi apakah parkirnya konvensional atau menggunakan jasa pihak ketiga. Jika menggunakan jasa pihak ketiga maka berlaku seperti keadaan normal. Pengecualiannya dapat berlaku hanya bagi internal BLU atau mengikuti perjanjian antara BLU dan pihak ketiga.

Pihak ketiga dapat berperan sebagai pihak yang menyelenggarakan tempat parkir yang dimiliki oleh BLU ataupun pihak yang mengelola tempat parkir milik BLU. Atas jasa penyediaan tempat parkir berbayar milik BLU oleh pihak ketiga merupakan ranah daerah berdasarkan UU PDRD. Sementara itu, atas penyerahan jasa pengelolaan tempat parkir yang dilakukan oleh pihak ketiga merupakan objek PPN. Jika kemudian pihak ketiga yang mengelola tempat parkir tersebut juga ditunjuk sebagai penyelenggara tempat parkir, maka pihak ketiga terkait dapat disebut sebagai perantara antara BLU dengan konsumen.

Hal ini berkaitan dengan penelitian Miftahudin dan Irawan (2020) yang mengemukakan bahwa terdapat peran penting dalam pemenuhan kewajiban PPN oleh konsumen yang dapat dimainkan oleh perantara atau intermediary yang terlibat dalam supply chain suatu usaha. Dalam kewenangannya, intermediary atau pihak ketiga tersebut dapat memungut, menyetor, dan melaporkan PPN. Mekanisme intermediary yang dapat memungut PPN secara umum telah sesuai dengan prinsip efektivitas dan efisiensi. Berarti, ketika pihak ketiga yang mengelola tempat parkir milik BLU ditunjuk sebagai penyelenggara tempat parkir, pihak ketiga tersebut berwenang untuk memungut PPN atas jasa pengelolaan tempat parkir.

\subsection{Pengenaan Pajak atas Parkir Berbayar dari BLU}

Pada dasarnya, perbedaan yang paling utama dari pengenaan pajak atas parkir berbayar dari BLU adalah dengan melihat pihak penyelenggara parkir berbayar tersebut. Ketentuan dalam UU PDRD mengecualikan pajak parkir atas penyelenggaraan tempat parkir oleh pemerintah dan pemerintah daerah. Di sisi lain, UU PDRD juga mengatur mengenai retribusi khusus tempat parkir yang dikenakan atas pelayanan tempat khusus parkir yang disediakan, dimiliki, atau dikelola oleh pemerintah daerah. BLU sebagai bagian dari pemerintah daerah dapat menyediakan tempat parkir dengan memungut bayaran kepada pengunjungnya.

Jika dilihat dari dua penjelasan tersebut, penyediaan tempat parkir berbayar oleh pemerintah daerah termasuk BLU merupakan objek retribusi tempat khusus parkir sehingga tidak termasuk objek pajak parkir. Retribusi yang terutang dapat dihitung berdasarkan hasil perkalian antara tingkat penggunaan jasa dengan tarif retribusi. Pemerintah daerah menetapkan tingkat penggunaan jasa yang dijadikan dasar alokasi beban biaya yang dipikul oleh BLU untuk menyelenggarakan layanan yang bersangkutan dan hal-hal lain terkait pemungutan retribusi. Ketentuan ini hanya berlaku apabila pihak BLU secara mandiri sebagai pemilik tempat parkir menyediakan dan menyelenggarakan parkir berbayar bagi pengunjungnya. 
Berkaitan dengan penyediaan tempat parkir berbayar oleh pemerintah daerah yang merupakan objek retribusi tempat khusus parkir, sebenarnya tiap daerah dapat menyesuaikan ketentuan yang ada dalam UU PDRD selama memang pemerintah pusat memberikan kewenangan terkait hal tersebut kepada daerah. Bahkan, pemerintah daerah dapat menyebutkan dalam peraturan daerahnya mengenai instansi-instansi tertentu termasuk BLU yang tidak dikenakan pajak parkir atas penyediaan tempat parkir berbayarnya. Hal ini merujuk pada penjelasan NS1 (2021) yang berpendapat misalkan di suatu daerah tertentu bisa saja BLU/BLUD ini tidak dikenakan parkir tapi bisa saja di daerah lain dikenakan. Itu bisa saja terjadi tergantung dari kebijakan daerah masingmasing. Yang penting statement yang tidak masuk objek pajak diatur dalam Perda.

Konsep mengenai pengertian pemilik tempat parkir, penyelenggara tempat parkir, dan pengelola tempat parkir merupakan sesuatu yang penting dalam menginterpretasikan pengenaan pajak atas parkir berbayar dari BLU. Penjelasan tersebut terdapat dalam PMK Nomor 122/PMK.03/2012 yang menjelaskan tentang kriteria jasa penyediaan tempat parkir yang termasuk dalam jenis jasa yang tidak dikenai PPN. Dalam PMK ini, disebutkan bahwa jasa penyediaan tempat parkir dapat dilakukan oleh pemilik tempat parkir ataupun pengusaha pengelola tempat parkir dalam menyediakan atau menyelenggarakan tempat parkir berbayar.

Dalam menjalankan kegiatannya sebagai suatu bagian dari penyelenggaraan tempat parkir berbayar, terdapat perjanjian kerja sama antara pihak BLU dengan pihak lain yang menyelenggarakan parkir berbayar tersebut. Sebagai contoh, di DKI Jakarta terdapat perjanjian antara BLU dengan pihak ketiga. Menurut Peraturan Gubernur Provinsi DKI Jakarta Nomor 72 tahun 2014 tentang Kerja Sama Penyelenggaraan Parkir, perjanjian kerja sama penyelenggaraan parkir di pelataran, gedung parkir, dan fasilitas parkir dapat dilaksanakan dalam beberapa bentuk sesuai dengan kesepakatan kedua belah pihak.

Pihak ketiga yang sebelumnya telah mendapatkan izin penyelenggaraan tempat parkir dari pemerintah setempat kemudian memungut bayaran atas parkir yang dilakukan oleh pengunjung. Beberapa contoh perusahaan parkir yang ada di Indonesia antara lain MSM Parking Group, Sky Parking, PT Anugerah Bina Karya (EZ Parking), PT ISS Parking Management (ISS Parking), dan PT Securindo Packtama Indonesia (Secure Parking). Secara umum, pihak ketiga akan tetap bersikap profesional sebagaimana ditetapkan dalam perjanjian kerja sama.

Namun, kembali lagi bahwa daerah dapat mengatur lebih lanjut mengenai mekanisme pengenaan pajak parkir sesuai dengan kondisi daerahnya. Misalkan di DKI Jakarta dan area metropolitan lain, terdapat banyak tempat komersial dan tempat usaha sehingga diperlukan lahan parkir pada kawasan tersebut. Tidak menutup kemungkinan juga bahwa atas satu gedung yang sama, terdapat beberapa macam instansi pemerintah bahkan pihak swasta. Penyelenggaraan tempat parkir di gedung tersebut dapat diserahkan kepada pihak ketiga.

Jika melihat kondisi yang ada, tidak sedikit BLU yang menggunakan pihak ketiga dalam penyelenggaraan parkir berbayar miliknya. Menurut NS3 (2021), penghitungan pajak parkir yang terutang dapat disesuaikan dengan ketentuan daerah masing-masing. Penghitungan ini juga tidak dapat terlepas dari perjanjian kerja sama antara BLU dan pihak ketiga, misalkan dengan persentase tertentu. Terkait dengan penghitungan ini, NS1 (2021) juga memberikan contoh misalkan Secure Parking, akan memungut pajak parkir dari pengunjung, Nanti dihitung misalkan pengunjung itu ada 100 dikali Rp5.000 berarti Rp500.000 ya. Misalkan itu jumlah per hari nanti dikalikan tarif pajak parkir. Jadi jika tarif pajak parkir di daerah itu adalah Rp500.000 di kali 30\% berarti Rp150.000. Itulah jumlah yang akan disetor oleh Secure Parking ke pemerintah daerah sebagai pajak parkir, sedangkan sisanya itu merupakan penerimaan dari pengelolaan tadi, pengelola perparkiran, bisa 


\section{5 | Bina Ekonomi}

berbentuk badan usaha. Jadi yang menjadi hak pemerintah daerah itu adalah $30 \%$ saja yang merupakan besaran tarif pajak parkir.

Lebih lanjut, setelah pajak parkir yang terutang tersebut diketahui jumlahnya, terdapat beberapa mekanisme terkait sebelum pihak ketiga menyetorkan pajak parkirnya. Terkait jumlah pajak parkir yang terutang, NS1 (2021) berpendapat setelah dikurangi pengecualian, ada pegawai yang parkir. Bagaimana mekanisme pengembaliannya itu diatur pemerintah daerah. Jadi nanti pajak parkirnya meskipun harian tapi setornya perbulan. Jadi dikurang dulu dengan hal-hal yang jadi pengurangan atau pengecualian.

Dengan konsep sebagaimana telah disampaikan oleh NS2, dapat digambarkan dalam sebuah contoh. Misalkan suatu BLU menyerahkan penyediaan parkirnya kepada pihak ketiga, misalkan Secure Parking. Tarif parkir yang ditetapkan oleh pihak ketiga adalah Rp2.000 untuk kendaraan bermotor roda dua dan Rp5.000 untuk kendaraan roda empat. Misalkan dalam satu hari terdapat 125 kendaraan roda dua dan 50 kendaraan roda empat yang parkir pada tempat parkir tersebut. Maka penghasilan yang diterima oleh Secure Parking dalam satu hari adalah Rp500.000. Jumlah sebesar Rp500.000 tersebut merupakan dasar pengenaan pajak yang secara umum akan dikenakan pajak parkir sesuai tarif yang ditetapkan oleh peraturan daerah.

Perlu diingat bahwa pengenaan pajak parkir menggunakan self-assesment system yang berarti wajib pajak berhak menentukan sendiri besarnya pajak terutang. Setelah menentukan dasar pengenaan pajak, maka jumlah pajak terutang dapat dihitung dengan mengalikan DPP dengan tarif pajak. Jika tarif pajak parkir yang ditetapkan adalah 30\%, maka dari penghasilan sebesar Rp500.000, jumlah senilai Rp150.000 merupakan jumlah yang akan disetor oleh Secure Parking ke pemerintah daerah sebagai pajak parkir.

Anggaplah bahwa penghasilan Secure Parking atas penyelenggaraan tempat parkir milik BLU tersebut dalam sehari merupakan jumlah yang cukup konsisten. Berarti, dalam satu bulan setidaknya Rp4.500.000 merupakan pajak parkir yang menjadi hak pemerintah daerah. Namun, perlu ditinjau kembali terkait adanya pengecualian atas parkir yang dibayarkan oleh pihak internal BLU seperti pegawai atau karyawan.

Menurut NS1 (2021), sejalan dengan pengecualian pengenaan pajak parkir, pegawai atau karyawan instansi terkait memiliki fasilitas khusus. Fasilitas tersebut merupakan kewenangan masing-masing instansi dan persetujuan dengan pihak ketiga yang menyelenggarakan tempat parkir berbayar milik BLU. Fasilitas tersebut dapat berupa kupon, penggantian biaya parkir, ataupun penggunaan kartu khusus untuk membedakan antara pihak internal BLU dengan pengunjung. NS1 juga menyatakan bahwa terdapat suatu mekanisme khusus terkait dengan adanya fasilitas tersebut yaitu berupa pengembalian atas parkir yang telah dipungut oleh pihak ketiga.

Penghitungan DPP merupakan urusan pihak ketiga selaku penyelenggara tempat parkir berbayar milik BLU. Dasar pengenaan pajak parkir adalah jumlah pembayaran atau yang seharusnya dibayar kepada penyelenggara tempat parkir, termasuk apabila terdapat potongan harga parkir dan parkir cuma-cuma. Dalam pengertian jumlah yang seharusnya dibayar, pemberian cuma-cuma dapat dihitung berdasarkan metode penghitungan tertentu. Masing-masing daerah dapat menetapkan cara penghitungan tersebut. Jumlah dari seluruh pembayaran atau yang seharusnya dibayar tersebut merupakan pendapatan kotor pihak ketiga atas parkir berbayar. Pihak ketiga biasanya menghitung jumlah tersebut secara harian berdasarkan tarif parkir yang telah disepakati pada perjanjian kerja sama dengan BLU.

Pendapatan harian tersebut kemudian diakumulasikan selama satu bulan penuh termasuk pengurangan jika terdapat fasilitas khusus bagi pegawai sebagaimana telah dijelaskan sebelumnya. 
Jika jumlah tersebut sudah sesuai dengan kesepakatan, maka dasar pengenaan pajak parkir beserta jumlah pajak parkir yang terutang dapat diketahui. Setelah menentukan besarnya pajak terutang, penyelenggara tempat parkir menyetorkan pajak parkir dan melaporkan surat pemberitahuan pajak daerah sesuai masa pajaknya.

Terkait jasa parkir, NS3 (2021) berpendapat bahwa parkir merupakan kewenangan daerah termasuk pengecualiannya. Tetapi lain halnya jika mengenai penyerahan jasa pengelolaan pajak parkir yang dikenai PPN. Berarti, di sisi lain terdapat PPN yang dikenakan atas penyerahan jasa pengelolaan tempat parkir. Jika kemudian pihak ketiga yang mengelola tempat parkir tersebut juga ditunjuk sebagai penyelenggara tempat parkir, maka pihak ketiga terkait dapat disebut intermediary yang dapat memungut, menyetor, dan melaporkan PPN.

PPN atas jasa ini dikenakan dengan DPP nilai penggantian yaitu nilai berupa uang, termasuk biaya yang diminta atau yang seharusnya diminta oleh pihak pengusaha pengelola tempat parkir kepada pemilik tempat parkir. Nilai penggantian yang dimaksud juga meliputi imbalan bagi hasil sesuai dengan perjanjian antara pengusaha pengelola tempat parkir dengan pemilik tempat parkir. Selanjutnya, jumlah PPN yang harus dipungut dapat diketahui dengan mengalikan DPP berupa nilai penggantian tersebut dengan tarif PPN yaitu $10 \%$.

PPN yang dipungut oleh pengusaha pengelola tempat parkir diberlakukan sebagai pajak keluaran yang akan diperhitungkan dengan pajak masukan yang sebelumnya telah dibayar oleh pengusaha pengelola tempat parkir. Hal ini sesuai dengan karakteristik PPN yaitu credit method yang berarti bahwa pajak yang terutang diperoleh dari hasil pengurangan pajak yang telah dipungut atau pajak keluaran dengan pajak yang telah dibayar atau disebut pajak masukan.. Atas selisih dari pajak keluaran yang lebih besar dari pajak masukan merupakan jumlah PPN yang harus disetor ke kas negara. Pengusaha pengelola tempat parkir menyetor dan melaporkan surat pemberitahuan masa PPN berdasarkan ketentuan yang berlaku.

\section{SIMPULAN}

Adanya negative list PPN dalam hubungannya dengan UU PDRD merupakan salah satu cara untuk menghindari pajak berganda atas suatu objek yang sama. Beberapa jenis objek pajak daerah merupakan kelompok barang atau jasa yang tidak dikenai PPN. Objek pajak daerah tersebut merupakan jenis pajak kabupaten atau kota yaitu pajak hotel, pajak restoran, pajak hiburan, dan pajak parkir. Jenis pajak tersebut berkaitan dengan negative list PPN berupa jasa perhotelan, kelompok makanan atau minuman, jasa boga atau katering, jasa pelayanan sosial, jasa kesenian dan hiburan, dan jasa penyediaan tempat parkir. Terkait jasa parkir, PPN hanya dikenakan atas penyerahan jasa pengelolaan tempat parkir yaitu atas pengelolaan yang dilakukan oleh pengusaha pengelola tempat parkir. Berbeda dengan penyerahan jasa penyediaan tempat parkir yang tidak dikenai PPN melainkan menjadi objek pajak daerah berupa pajak parkir. Berdasarkan UU PDRD, atas jasa parkir sendiri terdapat tiga jenis pungutan daerah yaitu pajak parkir, retribusi jasa umum, dan retribusi jasa usaha. Pajak parkir dikenakan atas penyelenggaraan tempat parkir di luar badan jalan termasuk penyediaan tempat penitipan kendaraan bermotor.. Retribusi jasa umum berupa retribusi pelayanan parkir dikenakan atas penyediaan pelayanan parkir di tepi jalan umum yang telah ditentukan berdasarkan peraturan daerah. Sementara retribusi jasa usaha berupa tempat khusus parkir dipungut atas pelayanan tempat khusus parkir baik yang disediakan, dimiliki, maupun dikelola oleh pemerintah daerah.

Parkir berbayar dari BLU secara umum merupakan salah satu pengecualian pengenaan pajak parkir menurut UU PDRD karena merupakan penyelenggaraan tempat parkir oleh pemerintah pusat 
dan pemerintah daerah. Namun, BLU dapat menggunakan jasa pihak ketiga untuk menyelenggarakan parkir berbayar dari tempat parkir miliknya. Jika melihat keterkaitannya dengan ketentuan PPN, pihak ketiga tersebut dapat berperan sebagai pihak yang menyelenggarakan tempat parkir yang dimiliki oleh BLU ataupun pihak yang mengelola tempat parkir milik BLU. Atas jasa penyediaan tempat parkir berbayar milik BLU oleh pihak ketiga merupakan ranah daerah berdasarkan UU PDRD. Sementara itu, atas penyerahan jasa pengelolaan tempat parkir yang dilakukan oleh pihak ketiga merupakan objek PPN.

Penyelenggaraan parkir berbayar oleh pemerintah daerah dalam hal ini yaitu BLU secara umum bukan merupakan objek pajak baik pajak parkir maupun PPN sepanjang tempat parkir berbayar tersebut disediakan langsung oleh pihak BLU. Atas bayaran yang dipungut oleh pihak BLU merupakan jenis retribusi jasa usaha berupa retribusi tempat khusus parkir yang disediakan khusus di area BLU. Ketentuan ini dapat berbeda jika dalam penyelenggaraannya dilakukan oleh pihak ketiga pada tempat parkir yang dimiliki baik oleh pemerintah pusat, pemerintah daerah, maupun BLU. Jika diselenggarakan oleh pihak ketiga, tidak menutup kemungkinan dapat dikenakan pajak parkir. Hal ini merujuk pada bagaimana perjanjian sewa penggunaan aset ketika lahan parkir milik BLU disewa oleh pihak ketiga dengan tarif yang ditetapkan oleh pihak ketiga. 


\section{DAFTAR PUSTAKA}

Abubakar, I., Sinaga, E. A., Budiarso, Sinulingga, T., Agung, T. G., Sembiring, N., Djajasinga, N., Surti, Betsy Hailah Ginting, R., Yani, A., Nurida, C., \& Sutiono, E. (1998). Pedoman Perencanaan dan Pengoperasian Fasilitas Parkir. Direktorat Jenderal Perhubungan Darat.

Amanto, S., \& Andri, S. (2014). Kontribusi pajak terhadap pendapatan asli daerah. Jurnal Administrasi Pembangunan, 2(2), 155-160.

Aprillitawati, D. (2013). Analisis efektivitas pajak parkir terhadap pendapatan asli daerah Kota Mojokerto. Jurnal Akuntansi AKUNESA, 1(3).

Arditia, R. (2013). Analisis kontribusi dan efektivitas pajak daerah sebagai sumber pendapatan asli daerah Kota Surabaya. Jurnal Akuntansi AKUNESA, 1(3).

Butarbutar, T. E. (2015). Analisa peranan pajak parkir terhadap peningkatan pendapatan asli daerah di Kota Tomohon. Jurnal EMBA: Jurnal Riset Ekonomi, Manajemen, Bisnis dan Akuntansi, 2(4).

Chandra, N. Y., Taufik, H., \& Sebayang, M. (2021). Analisis kelayakan finansial pembangunan gedung parkir Sukaramai Trade Center II. Jurnal Saintis, 21(01), 21-30.

Erawati, T., \& Rahmawati, N. (2016). Analisis efektifitas dan efisiensi pajak reklame, pajak parkir, pajak hiburan, produk domestik regional bruto (PDRB) dan pendapatan asli daerah (PAD) di Kabupaten Bantul. Jurnal Akuntansi, 4(1), 41-56.

Estiningsih, W., \& Nurranto, H. (2020). Analisis efektivitas pajak parkir dalam meningkatkan pendapatan asli daerah di wilayah Jakarta Selatan. Sosio e-Kons, 12(02), 172-183.

Fajriana, N. (2017). Analisis praktik pemungutan pajak parkir di Kota Batu. Jurnal Ilmiah Mahasiswa $F E B, 5(2)$.

Gandasari, M., Junaidi, J., \& Sari, A. F. K. (2020). Pengaruh pembayaran pajak parkir melalui e-parking dalam meningkatkan omzet pendapatan asli daerah Kota Surabaya. Jurnal Ilmiah Riset Akuntansi, 9(05).

Gintoe, S., Elim, I., \& Mawikere, L. M. (2018). Analisis peran pemungutan pajak parkir dalam peningkatan pendapatan asli daerah di Kota Bitung. Going Concern: Jurnal Riset Akuntansi, 13(04).

Gusful, A. (2015). PAD: Potensi pajak parkir di Kabupaten Wonosobo. Jurnal Penelitian dan Pengabdian Kepada Masyarakat UNSIQ, 2(1), 47-60.

Haikal, M. (2018). Studi pengembangan curbside dan parkir kendaraan di Bandara Sultan Iskandar Muda. ETD Unsyiah.

Hani, U., \& Djasuli, M. (2015). Menguak fenomena lorong-lorong gelap kebocoran pajak dan retribusi parkir. Pamator Journal, 8(2), 109-124. 
Haula, R., Irianto, E. S., \& Putranti, T. M. (2011). Teori Pajak Pertambahan Nilai: Kebijakan dan Implementasinya di Indonesia. Ghalia Indonesia.

Hutagalung, E. (2016). Perimbangan Keuangan Antara Pemerintah Pusat Dengan Pemerintah Daerah Dalam Pengelolaan Keuangan Daerah. Jurnal Ilmu Pemerintahan Widya Praja, 42(1), 1. https://doi.org/10.33701/jipwp.v42i1.137

Hutagalung, M. K. (2017). Perancangan prototive parkir meter portable. In Semantika (Seminar Nasional Teknik Informatika), 1(1), 16-24.

Kadaryanto, B., \& Utama, A. S. (2020). Penegakan hukum terhadap pelaksanaan pajak parkir di Kabupaten Pelalawan. Ensiklopedia Sosial Review, 2(1), 46-50.

Kasuma, I. N. (2011). Analisis kelayakan finansial rencana pembangunan gedung parkir bertingkat di Pasar Lokitasari. Universitas Udayana.

Peraturan Menteri Keuangan Nomor 122/PMK.03/2012 tentang Kriteria Jasa Penyediaan Tempat Parkir yang Termasuk dalam Jenis Jasa yang Tidak Dikenai Pajak Pertambahan Nilai, (2012).

Peraturan Menteri Keuangan Nomor 158/PMK.010/2015 tentang Kriteria Jasa Kesenian dan Hiburan yang Tidak Dikenai PPN, (2015).

Peraturan Menteri Keuangan Nomor 18/PMK.010/2015 tentang Kriteria Jasa Boga atau Katering yang Termasuk dalam Jenis Jasa yang Tidak Dikenai PPN, (2015).

Kementerian Keuangan. (2019). Mengenal Rasio Pajak Indonesia. https://www.kemenkeu.go.id/publikasi/berita/mengenal-rasio-pajak-indonesia/

Kesek, F. (2013). Efektivitas dan kontribusi penerimaan pajak parkir terhadap pendapatan asli daerah Kota Manado. Jurnal EMBA: Jurnal Riset Ekonomi, Manajemen, Bisnis, dan Akuntansi, $I(4)$.

Kormomolin, F., Taihuttu, F., \& Kempa, M. (10M). Penerapan value engineering pada pembangunan lahan parkir fakultas teknik Universitas Pattimura Ambon. Jurnal Simentrik, 1(295-301).

Kumaratih, C., Saadah, N., \& Ispriyarso, B. (2018). Pemungutan pajak atas parkir (Kajian perbandingan antara pajak atas parkir dan pajak penghasilan atas pengelolaan parkir). Universitas Diponegoro.

Landeng, C. M., Nangoi, G. B., \& Alexander, S. W. (2021). Evaluasi kontribusi dan efektivitas pajak parkir dan pajak reklame Kota Manado. Jurnal EMBA: Jurnal Riset Ekonomi, Manajemen, Bisnis dan Akuntansi, 9(2).

Le, T. M. (2003). Value Added Taxation: Mechanism, Design, and Policy Issues. Europe, 1-55.

Lubis, S. H., \& Yando, A. D. (2019). Faktor-faktor yang mempengaruhi penerimaan pajak parkir di Kota Medan. Journal of Accounting and Management Innovation, 3(1), 1-13.

Maharani, U. P., \& Rosyid, R. (2014). Analisis kontribusi pajak parkir pada pendapatan asli daerah (PAD). Jurnal Pendidikan dan Pembelajaran Khatulistiwa, 3(10). 
Makausi, A. M., Sabijono, H., \& Pinatik, S. (2019). Kontribusi dan efektivitas penerimaan pajak parkir terhadap pendapatan asli daerah Kota Gorontalo. Going Concern: Jurnal Riset Akuntansi, 14(4).

Malombeke, N. (2016). Analisis potensi dan efektivitas pemungutan pajak parkir di Kabupaten Minahasa Utara. Jurnal EMBA: Jurnal Riset Ekonomi, Manajemen, Bisnis dan Akuntansi, 4(1).

Manopo, B. S., Kalangi, L., \& Kalalo, M. Y. (2020). Evaluasi penerimaan retribusi kebersihan dan pajak parkir pada badan pendapatan daerah Kota Manado. Jurnal EMBA: Jurnal Riset Ekonomi, Manajemen, Bisnis dan Akuntansi, 8(4).

Mardiasmo. (2016). Perpajakan Edisi Revisi. Salemba Empat.

McNulty, J. K. (2000). Flat Tax, Consumption Tax, Consumption-Type Income Tax Proposals in the United States: A Tax Policy Discussion of Fundamental Tax Reform. California Law Review, 88(6), 2095. https://doi.org/10.2307/3481214

Miftahudin, A., \& Irawan, F. (2020). Alternatif kebijakan pajak pertambahan nilai atas konsumsi atau pemanfaatan konten dan jasa digital dari penyedia luar negeri. Scientax, 1(2), 131-148.

Moloeng, L. J. (2005). Metodologi Penelitian Kualitatif. Remaja Rosdakarya.

Mosal, M. M. (2013). Analisis efektivitas, kontribusi pajak parkir terhadap pendapatan asli daerah (PAD) dan penerapan akuntansi di Kota Manado. Jurnal EMBA: Jurnal Riset Ekonomi, Manajemen, Bisnis dan Akuntansi, I(4).

Mufidah, A., \& Susyanti, J. (6M). Analisis pengaruh pajak parkir, pajak restoran dan retribusi parkir terhadap pendapatan asli daerah Kota Malang (Studi kasus badan pengelola keuangan dan aset daerah Kota Malang). Jurnal Ilmiah Riset Manajemen, 02.

Mujib, A. (2020). Analisis investasi biaya tata kelola parkir terpadu wisata Teluk Prigi Kecamatan Watulimo Kabupaten Trenggalek. Universitas 17 Agustus 1945 Surabaya.

Mustoffa, A. F. (2018). Kontribusi dan efektivitas pajak daerah Kabupaten Ponorogo. Assets: Jurnal Akuntansi dan Pendidikan, 7(1), 1-14.

Mutiarahajarani, N., Hapsari, D. W., \& Kurnia, K. (2018). pengaruh pajak hotel, pajak restoran, pajak hiburan dan pajak parkir terhadap pendapatan asli daerah (Studi empiris pada Kota Tasikmalaya periode 2014-2016). eProceedings of Management, 5(2).

Nataherwin, \& Widyasari. (2017). Kupas Tuntas tentang PPN dan PPnBM. Rasi Terbit.

Nazir, M. (2013). Metode Penelitian. Ghalia Indonesia.

Noor, M. (2012). Memahami Desentralisasi Indonesia. Interpena Yogyakarta.

Nugroho, A. D. (2006). Penghindaran pajak berganda nasional di bidang perparkiran. Mimbar Hukum, 18(2006).

Pamasi, M. S., Saerang, D. P., \& Afandi, D. (2018). Analisis sistem penerimaan pajak parkir pada badan pengelola pajak dan retribusi daerah Kota Manado. Going Concern: Jurnal Riset Akuntansi, $13(04)$. 
Pangau, N. R., Tinangon, J. J., \& Gamaliel, H. (2019). Analisis efektivitas pajak parkir dan kontribusinya bagi penerimaan pajak daerah di Kota Tomohon. Jurnal EMBA: Jurnal Riset Ekonomi, Manajemen, Bisnis dan Akuntansi, 7(3).

Pangerapan, H., \& Wokas, H. R. (2016). Analisa potensi dan efektivitas sistem pemungutan pajak parkir dan pajak air tanah sebagai sumber pendapatan asli daerah Kota Manado. Jurnal EMBA: Jurnal Riset Ekonomi, Manajemen, Bisnis dan Akuntansi Jurnal EMBA: Jurnal Riset Ekonomi, Manajemen, Bisnis dan Akuntansi, 4(1).

Pashaputra, K., Effendi, A. S., \& Roy, J. (2017). Analisis efektivitas dan kontribusi penerimaan pajak parkir terhadap pendapatan asli daerah Kota Samarinda. Jurnal Ilmu Ekonomi Mulawarman (JIEM), 2(1).

Payu, B. R. (2014). Analisis Kontribusi Pajak Daerah Terhadap Pendapatan Asli Daerah Kota Gorontalo Boby Rantow Payu. Jurnal Akuntansi, 18(1), 141-150.

Peraturan Gubernur Provinsi DKI Jakarta Nomor 72 tahun 2014 tentang Kerja Sama Penyelenggaraan Parkir, (2014).

Prananda, I. S., Harimurti, F., \& Sunarti, S. (2020). Analisis kontribusi dan efektivitas pajak hotel, pajak restoran, dan pajak parkir terhadap pendapatan asli daerah (Studi Kasus Kota Surakarta dan Kota Yogyakarta tahun 2012-2018). Jurnal Akuntansi dan Sistem Teknologi Informasi, 16(2), 173-187.

Puspitasari, N. D. (2015). Analisa penerapan pengenaan pajak pertambahan nilai terhadap sewa tempat usaha (stand pasar) dan penyerahan jasa pengelolaan lahan parkir pasar di Pd. Pasar Surya Surabaya. Universitas Airlangga.

Rahmadhini, A. P. (2015). tingkat efektivitas dan kontribusi pajak parkir terhadap pendapatan asli daerah Jombang. Jurnal Akuntansi AKUNESA, 3(2).

Religia, D., \& Pratomo, D. (2014). Analisis pengaruh efektivitas pajak dan retribusi parkir terhadap efektivitas pendapatan asli daerah Kota Bandung tahun 2011 sampai 2013. Proceedings of Management, 1(3).

Rosyid, A., Made, A., \& Susilawati, R. A. E. (2015). Analisis pemungutan pajak parkir dalam meningkatkan pajak daerah Kota Malang. Jurnal Riset Mahasiswa Akuntansi, 3(2).

Sa'adah, N. (2018). Tinjauan Komparatif atas Pemungutan Pajak Parkir Sebagai Salah Satu Objek Pajak Kabupaten/Kota Dengan Beberapa Jenis Pajak Pusat. Administrative Law and Governance Journal, 1(2), 103-105. https://doi.org/10.14710/alj.v1i2.103-105

Satifah, Q. (2020). Tinjauan Kebijakan VAT Refund Demi Peningkatan Kunjungan Wisatawan Mancanegara. Karya Tulis Tugas Akhir.

Subagiyo, A. (2018). Analisis potensi pajak parkir dalam meningkatkan penerimaan pajak daerah di Kabupaten Karawang. Jurnal Reformasi Administrasi: Jurnal Ilmiah untuk Mewujudkan Masyarakat Madani, 5(2), 158-164.

Susanto, T. A. (2016). Tinjauan atas PPN Jasa Perparkiran. Karya Tulis Tugas Akhir. 
Tulandi, V. M., Sabijono, H., \& Rondonuwu, S. (2020). Analisis efektivitas pajak parkir dan kontribusinya terhadap pendapatan asli daerah (PAD) Kota Kotamobagu. Jurnal EMBA: Jurnal Riset Ekonomi, Manajemen, Bisnis dan Akuntansi, 8(4).

Tumanduk, L. R., Elim, I., \& Tirayoh, V. Z. (2021). Sistem dan prosedur penerimaan pajak parkir dan kontribusinya terhadap peningkatan pajak daerah di BPPRD di Kota Bitung. Jurnal EMBA: Jurnal Riset Ekonomi, Manajemen, Bisnis dan Akuntansi, 9(2).

Undang-Undang Republik Indonesia Nomor 42 Tahun 2009 Tentang Perubahan Ketiga Atas UndangUndang Nomor 8 Tahun 1983 Tentang Pajak Pertambahan Nilai Barang Dan Jasa Dan Pajak Penjualan Atas Barang Mewah. Diakses dari https://www.pajak.go.id/sites/default/files/2019-07/UU\%2042\%202009.pdf

Vamiagustin, V. (2014). Pengaruh pajak daerah terhadap pendapatan asli daerah (studi kasus pada dinas pendapatan Kota Batu tahun 2010-2012). Jurnal Administrasi Bisnis, 14(2).

Wicaksono, G., \& Puspita, Y. (2020). Analisis efektivitas, kontribusi, dan potensi penerimaan pajak parkir di Kabupaten Banyuwangi. Jurnal Riset Manajemen dan Bisnis (JRMB) Fakultas Ekonomi UNIAT, 5(1), 135-150.

Widjaya, N., Susyanti, J., \& Salim, M. A. (2018). Pengaruh pajak hotel, pajak reklame dan pajak parkir terhadap pendapatan asli daerah Kota Malang tahun 2015-2017. Jurnal Ilmiah Riset Manajemen, 7(14).

Widuri, R. P., Budiwibowo, S., \& Murwani, J. (2020). Analisis penerimaan pajak reklame dan pajak parkir dalam upaya peningkatan pendapatan asli daerah. In FIPA: Forum Ilmiah Pendidikan Akuntansi, 8(1).

Wong, S. (2015). The Wealth of Nations. London Business School Review, 26(3), 46-49. https://doi.org/10.1111/2057-1615.12058 